\title{
Pathotyping of Vibrio Isolates by Multiplex PCR Reveals a Risk of Virulent Strain Spreading in New Caledonian Shrimp Farms
}

\author{
Yannick Labreuche ${ }^{a, b,{ }^{*}}$, Laurane Pallandre ${ }^{a}$, Dominique Ansquer $^{a}$, José Herlin ${ }^{a}$, Billy Wapotro ${ }^{a}$ \\ and Frédérique Le Roux
}

\footnotetext{
a Département Lagons, Ecosystèmes et Aquaculture Durable en Nouvelle-Calédonie, IFREMER, Station de St. Vincent, B.P. 2059, 98846 Nouméa cedex, Nouvelle-Calédonie, France

b Equipe émergente Ifremer-UPMC "Génomique des Vibrio", FR2424 Station Biologique de Roscoff, Place Georges Teissier, 29682 Roscoff cedex, France
}

\author{
*: Corresponding author : Yannick Labreuche, email address : Tel.: (687) 352588 ; Fax : (687) 351177 \\ email address : yannick.labreuche@ifremer.fr
}

\begin{abstract}
:
Two recurring syndromes threaten the viability of the shrimp industry in New Caledonia, which represents the second largest export business. The "Syndrome 93" is a cold season disease due to Vibrio penaeicida affecting all shrimp farms, while the "Summer Syndrome" is a geographically restricted vibriosis caused by a virulent lineage of Vibrio nigripulchritudo. Microbiological procedures for diagnosis of these diseases are time-consuming and do not have the ability to discriminate the range of virulence potentials of $V$. nigripulchritudo. In this study, we developed a multiplex PCR method to simultaneously detect these two bacterial species and allow for pathotype discrimination. The detection limits of this assay, that includes an internal amplification control to eliminate any falsenegative results, were determined at $10 \mathrm{pg}$ purified DNA and $200 \mathrm{cfu} / \mathrm{ml}$. After confirming the effectiveness of our method using experimentally infected animals, its accuracy was compared to standard biochemical methods during a field survey using 94 samples collected over 3 years from shrimp farms encountering mortality events. The multiplex PCR showed very high specificity for the detection of $V$. penaeicida and $V$. nigripulchritudo (inclusivity and exclusivity $100 \%$ ) and allowed us to detect the spreading of highly pathogenic isolates of $V$. nigripulchritudo to a farm adjoining the "Summer Syndrome area." This assay represents a simple, rapid, and cost-effective diagnostic tool for implementing timely risk management decisions but also understanding the seasonal and geographical distribution of these pathogens.
\end{abstract}

Keywords: multiplex PCR, Internal Amplification Control (IAC), Vibrio penaeicida, Vibrio nigripulchritudo, shrimp, Litopenaeus stylirostris, diagnosis, virulence, syndrome 


\section{Introduction}

Crustaceans represent one of the most economically important global aquaculture sectors, worth in excess of $\$ 15.7$ billion USD in 2007 . However, the epizootic spread of a wide variety of pathogens, including viruses, bacteria, fungi and protozoa, has led to huge economic losses in the shrimp farming industry, threatening its economic viability and long-term sustainability in some regions of the world. In New Caledonia (South Pacific), the shrimp culture industry is based upon the Pacific blue shrimp Litopenaeus stylirostris and is regularly affected by two seasonal vibrioses responsible for acute mortality outbreaks in specific environmental conditions. The first one, named 'Syndrome 93', mainly occurs during the southern winter (from mid-May to mid-September) and is caused by Vibrio penaeicida [8, 24]. The second vibriosis, due to $V$. nigripulchritudo, occurs during the warm season (from midNovember to mid-April). This disease, also called 'Summer Syndrome', is geographically restricted, affecting 3 out of the 17 farms of the island, and can wipe out as much as $80 \%$ of a pond around day 55-60 of the 120-day grow-out period [6, 19, 10]. Today, these recurring epizootics threaten the sustainability of this industry, which represents the second largest export business in New Caledonia.

Solutions to control the occurrence and spread of bacterial diseases in marine invertebrates are scarce. The use of antibiotics has been banned in New Caledonian farming procedures, since it may contribute to the development of antibiotic-resistant pathogens and to the dissemination of resistance determinants between aquatic and anthropogenic sources [23, 5]. In addition, whilst there is mounting evidence for specific immune memory in crustaceans, including shrimp [15], it is not yet clear whether any memory to these Vibrio spp is elicited, preventing the use of vaccination as a strategy to reduce bacterial disease impact. In light of these limitations, an efficient control of bacterial pathogens relies on the development of rapid and discriminative tests to minimize the introduction and spread of pathogenic agents in non-infected shrimp rearing systems. Molecular-based detection methods, primarily PCR and real-time PCR, have been previously described to detect and quantify $V$. nigripulchritudo and $V$. penaeicida isolates from various environmental and clinical sample types [24, 7, 9]. However, some complications linked to these assays remain unresolved. First, these two bacterial species can co-exist in a shrimp farm as well as in animals. Since these methods target single species, two PCRs are needed for simultaneous detection of these pathogenic agents, rending the process costly and time-consuming. The 'Summer Syndrome' is caused by a virulent lineage of $V$. nigripulchritudo $[6,10]$. Experimental challenges have shown that strains belonging to this lineage exhibit different virulence patterns from moderately pathogenic (20-80\% mortality; MP) to highly pathogenic (80-100\% mortality; HP). Nonpathogenic isolates of $V$. nigripulchritudo (0-20\% mortality; NP) are genetically more diverse. Although existing tools allow the specific identification of strains from this lineage, they are not able to predict their virulence, mostly because of a lack of knowledge regarding the molecular determinants of $V$. nigripulchritudo pathogenesis. However, the recent sequencing of the complete genome of the $V$. nigripulchritudo HP strain SFn1 revealed the presence of two plasmids of 11.7 (pB1067) and $247.2 \mathrm{~kb}$ (pA1066), respectively [22, 18]. The distribution and polymorphism of these plasmids, which are absent from NP isolates, strongly suggest that they may be driving forces, as well as markers, for the emergence of the HP phenotype in this bacterial species.

The objective of the present study was to establish a multiplex PCR method containing a chimerical internal amplification control (IAC) to enable the simultaneous detection and typing of $V$. penaeicida and $V$. nigripulchritudo strains. The robustness and applicability of this assay was subsequently determined using field samples collected over 3 years from several shrimp farms facing mortality outbreaks. 


\section{Methods}

\subsection{Bacterial strains, media and DNA preparation}

Strains used for validation of the multiplex PCR are presented in Table 1 and have been previously described $[8,10]$. Type strains of different Vibrio species were provided by the Centre de Ressources Biologiques (CRB, La Tremblade, France), other bacterial species were obtained from the Pasteur Institute of New Caledonia (IPNC, Nouméa, New Caledonia). Vibrio were grown in Marine Broth (MB) or Marine Agar (MA) at $28^{\circ} \mathrm{C}$, other bacterial species being cultured in Luria-Bertani (LB) at $37^{\circ} \mathrm{C}$. Template DNA was purified from bacteria grown in broth culture with the High Pure ${ }^{\mathrm{TM}}$ PCR Template Preparation kit (Roche Diagnostics, New Zealand) following manufacturer's instructions for "isolation of nucleic acids from bacteria". In the case of hemolymph samples or seawater suspensions, DNA was extracted following the "whole blood" instructions, except that each sample was incubated with $5 \mu$ lysozyme (10 mg. $\mathrm{ml}^{-1}$ in $10 \mathrm{mM}$ Tris- $\mathrm{HCl}, \mathrm{pH} 8.0$ ) for $1 \mathrm{~h}$ at $37^{\circ} \mathrm{C}$ before carrying out the procedure.

\subsection{Selection of target genes and oligonucleotide primer design}

Two genes, gyrB and gapA, were selected for differential detection of $V$. nigripulchritudo and $V$. penaeicida species, respectively. To design species-specific primers, gyrB and gapA gene sequences of $V$. penaeicida and $V$. nigripulchritudo along with 28 published sequences of other vibrios were downloaded from GenBank or retrieved from previously published work [10]. Sequences were aligned using the BioEdit software to identify species-specific conserved regions. Primers for $V$. penaeicida gapA gene were designed using the Primer 3 software (http://frodo.wi.mit.edu/primer3/), while primers for $V$. nigripulchritudo gyrB gene were deduced from previously designed oligonucleotides with some modifications [9] (Table 2). To differentiate MP from HP strains within the 'Summer Syndrome' lineage of $V$. nigripulchritudo, we used previously designed primers (namely pSFn1-6020 and pSFn16974) [27]. These primers target a 954-bp fragment of plasmid pB1067 evidenced only in the $\mathrm{HP}$ isolates [22]. Finally, to distinguish MP from NP isolates, we designed a primer pair targeting the rtxA gene of plasmid pA1066 from V. nigripulchritudo.

\subsection{Construction of a competitive internal amplification control (IAC)}

To identify false-negative results, an IAC was constructed in competition with the primers targeting the $r$ tXA gene of $V$. nigripulchritudo using plasmid pUC19 and the procedure of Abdulmawjood et al. [1]. Briefly, the IAC primer set had 5'overhanging ends identical to the rtxA gene primer and 3'ends complementary to the pUC19 sequence (Table 2). These primers generate a 376-bp product, including the flanking regions of the primer set. Following PCR amplification, the product was purified using the QIAquick Gel Extraction kit (QIAGEN) and titrated using a NanoDrop ${ }^{\text {ND }} 1000$ Spectrophotometer (NanoDrop Technologies). The IAC copy number was calculated as the amount of template $\times N_{A} /$ length of template $\times 1.10^{9} \times \mathrm{Mbp}$, where $N_{\mathrm{A}}$ is Avogadro's number $\left(6.022 \times 10^{23} \mathrm{~mol}^{-1}\right)$ and $\mathrm{Mbp}$, the mean molar mass of a base pair $\left(650 \mathrm{~g} \mathrm{~mol}^{-1}\right)$.

\subsection{PCR protocol}

Before optimization in a multiplex PCR, each primer pair was tested individually using DNA extracts of either $V$. nigripulchritudo SFn1 (representative HP isolate) or V. penaeicida AM101 (reference New Caledonian isolate) as templates. PCR was carried out on a GeneAmp ${ }^{R}$ PCR system 9700 thermocycler (Applied Biosystems) or on a MJ ${ }^{T M}$ Mini thermal cycler (BioRad) in a $20 \mu \mathrm{l}$ volume containing genomic DNA, $2 \mu \mathrm{l}$ of $10 \times$ PCR buffer, $200 \mu \mathrm{M}$ 
dNTP and $1 \mathrm{U}$ of HotStartTaq DNA polymerase. Two parameters were optimized: the annealing temperature and the primer concentration (ranging from 0.2 to $0.8 \mu \mathrm{M}$ in $0.2 \mu \mathrm{M}$ increments). The PCR program contained the following steps: initial denaturation of $15 \mathrm{~min}$ at $95^{\circ} \mathrm{C}$ followed by 35 cycles of denaturation at $95^{\circ} \mathrm{C}$ for $30 \mathrm{~s}$, primer annealing at $50-70^{\circ} \mathrm{C}$ for $30 \mathrm{~s}$, extension at $72^{\circ} \mathrm{C}$ for $30 \mathrm{~s}$, and a final extension at $72^{\circ} \mathrm{C}$ for $5 \mathrm{~min}$. PCR products were subjected to electrophoresis on $1.5 \%$ agarose gels containing GelRed ${ }^{\mathrm{TM}}$ DNA stain. To confirm their identity, representative amplicons for each target gene were gel-purified and sequenced by a commercial facility (GATC Biotech AG, Konstanz, Germany). Before including the IAC to each reaction, 5-fold dilutions of the IAC template (ranging from $2.8 \times 10^{8}$ to 28 copies) were tested in a conventional PCR using rtxA gene primer (rtxA F and rtxA R) to determine the lowest IAC DNA concentration giving a reliable PCR band visible by gel electrophoresis.

\subsection{Specificity and sensitivity assays}

The specificity of the 4 primer sets was assessed together by a multiplex PCR. Reactions were carried out following the previously optimized conditions, using $2 \mu \mathrm{l}$ of purified DNA and 284 copies of IAC. The detection limits of the assay were determined on DNA extracted from different sample types: shrimp hemolymph, artificial seawater and broth cultures. To this end, exponentially grown V. nigripulchritudo SFn1 or V.penaeicida AM101 cultures were subjected to 10 -fold serial dilutions in $1 \mathrm{ml}$ of artificial seawater or hemolymph, collected as previously described [18]. Viable plate counts were performed in duplicates on MA to determine the cfu/ml of each sample, while DNA extractions were carried out from $200 \mu \mathrm{l}$ aliquots as described above. The extracted DNA from each sample was used for multiplex PCR amplification, all samples being analyzed in duplicates. In addition, the efficiency of the assay was checked using purified genomic DNA $\left(\mathrm{OD}_{260 / 280} \geq 1.7\right)$ Template DNA was 10 -fold diluted in water from $10 \mathrm{ng}$ to $0.1 \mathrm{pg}$, and aliquots from each of the diluted samples were used for multiplex PCR amplifications.

\subsection{Detection of $V$. nigripulchritudo and $V$. penaeicida in experimentally infected shrimp}

Experimental infections were performed by immersion of the shrimp in aerated seawater containing $10^{5} \mathrm{cfu} / \mathrm{ml}$ of the considered Vibrio strain, as previously described [18]. Three replicate tanks were used for each treatment (i.e. control, experimentally infected with $V$. nigripulchritudo SFn1 and experimentally infected with $V$. penaeicida AM101). 24 hours after infection, 2 shrimp from each tank were randomly sampled. Hemolymph collection, DNA extraction and plate counts were performed as described above.

\subsection{Application of the method to field samples}

From January 2008 to December 2010, shrimp were sampled during mortality outbreaks occurring in 10 different shrimp farms located on the southwest coast of New Caledonia (Figure 3). This survey was conducted in the context of a health surveillance and monitoring program set up by Ifremer and the New Caledonian government veterinary laboratory. Shrimp were collected from ea $V$. nigripulchritudo cells were identified as black colonies in the presence of glycerol [2]. Obtained data were interpreted according to the Bergey's manual of determinative bacteriology (9th ed.). In parallel, these isolates were also analyzed by the multiplex PCR method. When isolates belonging to the $V$. nigripulchritudo species were identified as HP by the assay, their pathotype was confirmed by injecting shrimp with bacterial culture supernatants. Details of supernatant preparation and injection have been previously described [18]. Finally, when isolate identification showed discordant results 
between the two methods, 16S rRNA gene amplification was performed by PCR using eubacterial primers 1080.r (5'-GGG ACT TAA CCC AAC ATC T-3') and 370.f (5'-GGC AGC AGT GGG GAA TAT TG-3').rthen ponds by castnet operation, brought to the laboratory in an iced box and immediately processed for bacteriological analyses. One drop of hemolymph was aseptically withdrawn from the shrimp ventral sinus using a 1-ml plastic syringe fitted with a 25-gauge needle and plated on to MA and MA supplemented with $2 \%$ glycerol $(\mathrm{w} / \mathrm{v})$. Following incubation at $28^{\circ} \mathrm{C}$ for $48 \mathrm{~h}$, presumptive identification of bacterial isolates to the species level was done by a series of phenotypic tests which included cell morphology and motility, oxidase activity and API 20E (BioMérieux, Marcy L'Etoile, France). Putative

\section{Results}

\subsection{Determination of annealing temperature, primer concentration and IAC copy number}

The annealing temperature and concentrations of individual primer pairs were optimized to allow for efficient amplification of the target genes all together. The annealing temperature for the multiplex PCR assay was established at $66^{\circ} \mathrm{C}$, while optimum primer concentrations giving the best resolution were found to be $0,4 \mu \mathrm{M}$ for gyrB (F/R), gapA (F/R) and $r t x A(F / R)$ primers and $0,8 \mu \mathrm{M}$ for the pSFn1-6020/pSFn1-6974 primer set (data not shown). Using these optimized PCR conditions, a concentration of 284 IAC copies was determined as the lowest number enabling reproducible IAC amplification visible by gel electrophoresis (data not shown).

\subsection{Specificity of multiplex PCR assays}

In multiplex PCR, all the members of the $V$. nigripulchritudo species $(n=45)$ were successfully detected with the gyrB primers, yielding a 257-bp amplicon, irrespective of their isolation place, source and year (Table 1). As indicated in this Table, $V$. nigripulchritudo MP and HP strains $(n=28)$ exhibited the expected band of $257 \mathrm{bp}$ for gyrB and $642 \mathrm{bp}$ for $r t x A$, while HP isolates only $(n=17)$ exhibited an additional band of $954 \mathrm{bp}$ corresponding to the plasmid pB1067. All the $V$. penaeicida strains tested $(n=18)$ yielded a 376-bp amplicon for IAC and 504-bp amplicon for gapA, regardless of the year or site of isolation. The sequencing of the PCR products confirmed the specificity of the amplification (data not shown). No amplicon, except IAC, was observed in the case of nontarget vibrios $(n=10)$ or other bacterial species $(n=4)$, demonstrating the specificity of the assay.

\subsection{Evaluation of the detection limits}

The multiplex PCR assay worked efficiently with purified genomic DNA extracted from $V$. penaeicida AM101 and V. nigripulchritudo SFn1 individually, as well as in combination. The minimum DNA quantity necessary to detect the 4 PCR amplicons with the same band intensity was determined at $1 \mathrm{pg}$ when IAC DNA was not added to the PCR mix (data not shown), and at $10 \mathrm{pg}$ when using 284 copies of IAC (Figure 1, lane 4). At this concentration, the IAC coamplified with target DNA, as shown in Figure 1. Using 10-fold serial dilutions in artificial seawater or in hemolymph, the detection limits were found to be about $200 \mathrm{cfu} / \mathrm{ml}$ for $V$. penaeicida AM101 and V. nigripulchritudo SFn1, as determined by the plate count method (Figure $2 \mathrm{~A}$ and $2 \mathrm{~B}$, lanes 5). No difference in band intensity was noticed when the multiplex PCR was carried out with DNA extracted from bacterial cell suspensions prepared in seawater or in shrimp hemolymph (data not shown). 


\subsection{Detection of $V$. nigripulchritudo and $V$. penaeicida in experimentally infected shrimp}

The applicability of the multiplex PCR to detect these two species in non-symptomatic animals was evaluated using shrimp experimentally infected with these two pathogens and sampled before the onset of mortalities (i.e. $24 \mathrm{hrs}$ post-challenge). In uninfected (control) shrimp, no presumptive $V$. nigripulchritudo isolates (determined as black colonies among total heterotrophic bacteria on MA supplemented with $2 \%$ glycerol) could be detected by viable plate counts in hemolymph samples. Presumptive isolates of $V$. penaeicida were not detected, since this method did not permit the phenotypical distinction of this bacterial species among the endogenous microflora. When analyzed by multiplex PCR, these 6 samples were found negative for $V$. penaeicida detection (Supplementary data, Figure S1 A; lanes 1-6). However, one sample (Supplementary data, Figure S1 A; lane 3) exhibited a 257bp amplicon, indicating the presence of bacterial cells belonging to the $V$. nigripulchritudo species within the microflora of this animal. In shrimp challenged with strain SFn1, presumptive $V$. nigripulchritudo cells ranged between 100 and $4.10^{3} \mathrm{cfu} / \mathrm{ml}$ as determined by the viable plate count method. Multiplex PCR analysis, used to ascertain the presence of this species in infected animals, showed that 4 out of 6 samples (Supplementary data, Figure S1 B; lanes 8, 9, 10 and 12) generated the 3 amplicons corresponding to the expected PCR profile for $V$. nigripulchritudo HP isolates. Considering shrimp challenged with strain AM101, multiplex PCR analysis allowed the amplification of a 504-bp amplicon in 5 out of 6 hemolymph samples (Supplementary data, Figure S1 C; lanes 13, 15, 16, 17 and 18), indicating the presence of $V$. penaeicida cells within the circulatory system of these shrimp. Interestingly, a 257-bp amplicon corresponding to the PCR product obtained in the presence of the $V$. nigripulchritudo species was also detected in 3 of these samples. The IAC was amplified in all samples analyzed by multiplex PCR.

\subsection{Application of the method to field samples}

From January 2008 to December 2010, a total of 94 isolates was collected from moribund shrimp sampled in 10 different farms facing mortality outbreaks (Figure 3). Of these 94 samples, $48.9 \%$ were assigned to the $V$. nigripulchritudo species by means of phenotypic tests, while $36.2 \%$ were presumptively identified as belonging to $V$. penaeicida (Table 3 ). Fourteen strains (14.9\%) could not be assigned to any bacterial species because of the lack of resolution power of these tests. A comparison of the multiplex PCR results and phenotypic characterization showed that all the isolates biochemically identified as $V$. nigripulchritudo were also detected as belonging to this bacterial species in PCR, while 4 isolates that could not be determined after phenotypic characterization were identified by multiplex PCR as $V$. nigripulchritudo (Table 3). Of the 34 isolates presumptively identified as $V$. penaeicida, 32 were assigned to this bacterial species in multiplex PCR. On the basis of 16S rRNA gene sequence identity, the samples showing discordant results between the two methods were shown to belong to the Harveyi clade of the genus Vibrio (data not shown). Among the 50 isolates identified by multiplex PCR as belonging to the $V$. nigripulchritudo species, $26 \%$ were characterized as MP, while $32 \%$ were detected as HP. MP strains were recovered from 5 farms (i.e. farms A, D, E, I and J), while HP strains were detected in 3 locations (i.e. farms $\mathrm{G}, \mathrm{I}$ and $\mathrm{H}$ ). Previous studies showed that supernatant toxicity was a characteristic of HP but not MP strains [18], therefore shrimp were injected with supernatants prepared from these isolates to strengthen our pathotype determination. As shown in Figure 4, 0\% mortality was observed one day post-injection in control shrimp, whereas $75-100 \%$ cumulative mortality occurred in animals challenged with supernatants prepared from all the strains characterized as HP. 


\section{Discussion}

$V$. nigripulchritudo and $V$. penaeicida tracking is of interest for disease control programs or epidemiological studies concerned with the ecology and natural history of these diseases. However, conventional phenotypic approaches for diagnosis of vibriosis present a number of limitations, such as the time required to obtain confirmatory results, generally too long for practical management decisions, or the great variability in the biochemical characteristics of the Vibrionaceae, that renders their phenotypic identification on this basis particularly difficult. Commonly used molecular techniques may provide an efficient means of identifying a bacterial species [26]. However, these typing approaches do not have the ability to discriminate the range of virulence potentials of the $V$. nigripulchritudo species. To simultaneously detect these bacterial species and allow for pathotype discrimination, we therefore combined in a multiplex PCR assay two species-specific primer sets along with $V$. nigripulchritudo virulence biomarkers. Critical parameters of such an assay rely on the choice of the target genes and the design of corresponding primers. Because of lateral gene transfers, hidden paralogy or chromosomal rearrangements, any phylogenetic marker for the identification of Vibrio spp will have weaknesses and strengths [26]. For instance, the 16S rRNA gene has been widely used for species definition and identification among bacteria, but is of limited value in Vibrio spp because of its low taxonomic resolution [11]. As alternative taxonomic markers, we therefore selected gyrB and gapA, two highly conserved housekeeping genes commonly found in vibrios and previously demonstrated to possess the discriminating potential for the development of species-specific PCR primers [17, 9]. The results obtained with these 2 primer sets were shown to be accurate and highly specific to their corresponding target species, since no band was amplified from any of the nontarget Vibrio spp or other tested species. To screen the virulence potentials of $V$. nigripulchritudo strains, we also included in the assay primers targeting two different plasmids. The first primer set was previously designed and specifically amplifies a 954-bp fragment of plasmid pB1067, only found in HP strains [27], while the second set targets a rtxA toxin gene, located on a larger replicon, pA1066, and found in HP and MP strains only [18]. We used a collection of $45 \mathrm{~V}$. nigripulchritudo strains, whose virulence patterns were previously determined, and $18 \mathrm{~V}$. penaeicida isolates to validate the pathotyping ability and specificity of our multiplex PCR. Data presented herein demonstrate that this method shows a very efficient discriminating potential, since our results matched exactly with those obtained in a previous study by means of experimental challenges [6]. Among the limitations to using PCR as a diagnostic tool, there is the risk of DNA contamination, that can induce false-positive reactions, and also the presence of inhibitory substances found in biological samples or in the environment that may produce false-negative PCR result [28]. To avoid this potential bias, we synthesized and integrated in the assay an IAC competitive with the gyrB gene of $V$. nigripulchritudo generating a control signal even when there is no target sequence present. The drawback of this strategy is that the IAC may decrease the amplification efficiency and thus the detection limit of the reaction $[1,13]$. In our assay, we established that 284 copies was the lowest concentration enabling reproducible IAC amplification visible by gel electrophoresis. At this concentration, a slight competition between IAC and the target DNA occurred, as we observed a 10-fold lowering of the detection limit. However, even with the presence of the IAC, we showed that the sensitivity of our PCR (established at $10 \mathrm{pg}$ purified DNA and $200 \mathrm{cfu} / \mathrm{ml}$ ) was consistent with the multiplex PCR methods described for the identification of other vibrios (between 1 and $10^{3} \mathrm{cfu} / \mathrm{ml}$ or between 10 and $100 \mathrm{pg}$ for DNA) $[4,20,12,25]$.

We tested the effectiveness of our method using hemolymph samples from experimentally challenged prawns. We showed that the multiplex PCR evidenced $V$. penaeicida as well as $V$. nigripulchritudo HP cells in infected animals before the onset of mortality. The presence of isolates belonging to $V$. nigripulchritudo was also detected in uninfected control shrimp as well as in shrimp challenged with $V$. penaeicida, while no putative $V$. nigripulchritudo colonies could be enumerated on the corresponding glycerol-supplemented marine agar plates. Since 
it as been previously reported that $30 \%$ of the bacterial flora of apparently healthy shrimp was Vibrio sp. [3], it is not surprising to detect isolates from the $V$. nigripulchritudo species in the shrimp circulatory system. Such results exemplify the need of pathotyping, since the detection of $V$. nigripulchritudo isolates is not necessarily linked to pathogenicity, as previously reported [6].

Finally we used the multiplex PCR to evaluate the occurrence of these two bacterial species using field samples collected from shrimp farms encountering mortality peaks from January 2008 to December 2010. We showed that $87.2 \%$ of the isolates could be identified by our assay as $V$. penaeicida or $V$. nigripulchritudo, confirming the major epidemiological importance of these 2 species in recurring mortality events of cultured shrimp in NewCaledonia. Supporting previous works $[10,19]$, we also observed a clear seasonal isolation pattern. The isolation rate of $V$. nigripulchritudo strains (72\%) was highly correlated with the summer period, and thus the water temperature, while $80 \%$ of the isolates collected during the southern winter were identified as $V$. penaeicida. Such strong relationship has been documented for other Vibrio species [21, 14] and temperature changes are considered as one of the most frequently used cues controlling the expression of numerous virulence factors in pathogenic bacteria [16]. However, it remains to be investigated whether this environmental signal plays some role in vibrio abundance or may modulate virulence factor expression in V. penaeicida and V. nigripulchritudo. As of 2007, the virulent lineage of $V$. nigripulchritudo HP strains implicated in the 'Summer Syndrome' was evidenced in one particular area of New Caledonia (i.e. the Saint Vincent Bay, an estuarine area of the southwestern lagoon), causing the disease in 3 farms only, including farms $\mathrm{G}$ and $\mathrm{H}$. The multiplex PCR allowed us to confirm the presence of the HP pathotype in these two locations but also to report, for the first time, its occurrence in another neighbouring farm (farm I), leading us to suspect the disease extension. Bacterial supernatant toxicity being a HP-specific feature [18], we confirmed our pathotype determination by in vivo experimental infection and showed congruent results between the two approaches. The results of this 3-year field study also revealed the yearly recurrence of HP isolates in the environment of these facilities. To date, the environmental reservoir of $V$. nigripulchritudo remains to be determined, although shrimp pond sediments are suspected to represent an ecosystem favoring bacterial persistence between crops in the affected farms and/or pathogen transmission to the host $[6,27]$. Finally, our multiplex PCR assay identified MP strains in both 'Summer Syndrome'-affected and nonaffected farms all along the West coast of the island, confirming previous data indicating that pathogenic and non-pathogenic strains co-exist in the same environment and at the same time [9].

To conclude, this assay represents a simple, rapid and cost-effective tool for diagnosis and implementing timely risk management decisions. This should not only help epidemiologists to better estimate the incidence of Vibrio infections in aquaculture systems and the associated risk of spreading of these diseases, but also provide an efficient tool for ecologists to understand the seasonal and geographical distribution as well as the effects of environmental parameters (such as temperature) on these two pathogens and associated diseases.

\section{Acknowledgments}

This work was supported by the DEDUCTION project funded by the Institut Français de Recherche et d'Exploitation de la Mer (IFREMER), the Provincial Institutions (Province Sud, Province Nord et Province des lles Loyauté) and by the Government of New Caledonia. Thanks are due to the zootechnical staff of IFREMER (P. Brun, E. Pita and A. Matehau) and to B. Soulard for map drawing. The authors warmly thank Pr. Gregory W. Warr for the critical review of the manuscript and for his help in editing the English language. Any opinions, findings and conclusions or recommendations expressed in this material are those of the authors and do not necessarily reflect the views of the supporting bodies mentioned herein. 
[1] Abdulmawjood A, Roth $S$ and Bülte $M$ (2002) Two methods for construction of internal amplification controls for the detection of Escherichia coli 0157 by polymerase chain reaction. Mol Cell Probes 16: 335-9

[2] Baumann P and Schubert R H W (1984) Section 5. Facultatively anaerobic Gramnegative rods, Family II. Vibrionaceae. Bergey's Manual of Systematic Bacteriology 1 516-50. ed. Holt, J.G. and Krieg, N.R., Baltimore, MD: Williams \& Wilkins Co

[3] Costa R, Mermoud I, Koblavi S, Morlet B, Haffner P, Berthe F, Legroumellec M and Grimont P (1998) Isolation and characterization of bacteria associated with a Penaeus stylirostris disease (Syndrome 93) in New Caledonia. Aquaculture 164: 297309

[4] Espiñeira M, Atanassova M, Vieites JM and Santaclara FJ (2010) Validation of a method for the detection of five species, serogroups, biotypes and virulence factors of Vibrio by multiplex PCR in fish and seafood. Food Microbiology 27: 122-31

[5] Furushita M, Shiba T, Maeda T, Yahata M, Kaneoka A, Takahashi Y, Torii K, Hasegawa T and Ohta M (2003) Similarity of Tetracycline Resistance Genes Isolated from Fish Farm Bacteria to Those from Clinical Isolates. Appl Environ Microbiol. 69: 5336-42

[6] Goarant C, Ansquer D, Herlin J, Domalain D, Imbert F and de Decker S (2006) "Summer Syndrome" in Litopenaeus stylirostris in New Caledonia: Pathology and epidemiology of the etiological agent, Vibrio nigripulchritudo. Aquaculture 253: 105-13

[7] Goarant C and Mérien F (2006) Quantification of Vibrio penaeicida, the etiological agent of Syndrome 93 in New Caledonian shrimp, by real-time PCR using SYBR Green I chemistry. J. Microbiol Methods 67: 27-35

[8] Goarant C, Mérien F, Berthe F, Mermoud I and Pérolat P (1999) Arbitrarily primed PCR to type Vibrio spp. pathogenic for shrimp. Appl Environ Microbiol 65: 1145-51

[9] Goarant C, Reynaud Y, Ansquer D, De Decker S and Merien F (2007) Sequence polymorphism-based identification and quantification of Vibrio nigripulchritudo at the species and subspecies level targeting an emerging pathogen for cultured shrimp in New Caledonia. J Microbiol Methods 70: 30-8

[10] Goarant C, Reynaud Y, Ansquer D, de Decker S, Saulnier D and le Roux F (2006) Molecular epidemiology of Vibrio nigripulchritudo, a pathogen of cultured penaeid shrimp (Litopenaeus stylirostris) in New Caledonia. Syst Appl Microbiol 29: 570-80

[11] Gupta RS (1998) Protein phylogenies and signature sequences: a reappraisal of evolutionary relationships among archaebacteria, eubacteria, and eukaryotes. Microb Mol Biol Rev 62: 1435-91

[12] Haldar S, Chatterjee S, Sugimoto N, Das S, Chowdhury N, Hinenoya A, Asakura M and Yamasaki S (2011) Identification of Vibrio campbellii isolated from diseased farmshrimps from south India and establishment of its pathogenic potential in an Artemia model. Microbiology 157: 179-88

[13] Hoorfar J, Malorny B, Abdulmawjood A, Cook N, Wagner M and Fach P (2004) Practical Considerations in Design of Internal Amplification Controls for Diagnostic PCR Assays. J Clin Microbiol. 42: 1863-8

[14] Johnson CN, Flowers AR, Noriea NF, III, Zimmerman AM, Bowers JC, DePaola A and Grimes DJ (2010) Relationships between Environmental Factors and Pathogenic Vibrios in the Northern Gulf of Mexico. Appl Environ Microbiol. 76: 7076-84

[15] Johnson KN, van Hulten MCW and Barnes AC (2008) "Vaccination" of shrimp against viral pathogens: Phenomenology and underlying mechanisms. Vaccine 26: 4885-92

[16] Konkel M E and Tilly K (2000) Temperature-regulated expression of bacterial virulence genes. Microbes Infect 2: 157-66

[17] Le Roux F, Gay M, Lambert C, Nicolas J L, Gouy M and Berthe F (2004) Phylogenetic study and identification of Vibrio splendidus-related strains based on gyrB gene sequences. Dis Aquat Organ 58: 143-50 
[18] Le Roux F, Labreuche Y, Davis BM, Iqbal N, Mangenot S, Goarant C, Mazel D and Waldor MK (2010) Virulence of an emerging pathogenic lineage of Vibrio nigripulchritudo is dependent on two plasmids. Environ Microbiol 13: 296-306

[19] Lemonnier H, Herbland A, Salery L and Soulard B (2006) "Summer syndrome" in Litopenaeus stylirostris grow out ponds in New Caledonia: Zootechnical and environmental factors. Aquaculture 261: 1039-47

[20] Panicker G, Vickery M C and Bej AK (2004) Multiplex PCR detection of clinical and environmental strains of Vibrio vulnificus in shellfish. Can J Microbiol. 50: 911-22

[21] Pfeffer CS, Hite MF and Oliver JD (2003) Ecology of Vibrio vulnificus in Estuarine Waters of Eastern North Carolina. Appl Environ Microbiol. 69: 3526-31

[22] Reynaud Y, Saulnier D, Mazel D, Goarant C and Le Roux F (2008) Correlation between detection of a plasmid and high-level virulence of Vibrio nigripulchritudo, a pathogen of the shrimp Litopenaeus stylirostris. Appl Environ Microbiol 74: 3038-47

[23] Rhodes G, Huys G, Swings J, Mcgann P, Hiney M, Smith P and Pickup RW (2000) Distribution of Oxytetracycline Resistance Plasmids between Aeromonads in Hospital and Aquaculture Environments: Implication of Tn1721 in Dissemination of the Tetracycline Resistance Determinant Tet A. Appl Environ Microbiol. 66: 3883-90

[24] Saulnier D, Avarre JC, Le Moullac G, Ansquer D, Levy P and Vonau V (2000) Rapid and sensitive PCR detection of Vibrio penaeicida, the putative etiological agent of syndrome 93 in New Caledonia. Dis Aquat Organ 40: 109-15

[25] Teh CSJ, Chua KH and Thong KL (2010) Simultaneous differential detection of human pathogenic and nonpathogenic Vibrio species using a multiplex PCR based on gyrB and pntA genes. J Appl Microbiol. 108: 1940-5

[26] Thompson F L, lida T and Swings J 2004 Biodiversity of vibrios. Microbiol Mol Biol Rev. 68(3): 403-31

[27] Walling E, Vourey E, Ansquer D, Beliaeff B and Goarant C (2010) Vibrio nigripulchritudo monitoring and strain dynamics in shrimp pond sediments. J Appl Microbiol. 108: 2003-11

[28] Wilson IG (1997) Inhibition and facilitation of nucleic acid amplification. Appl. Environ Microbiol. 63: 3741-51 


\section{Tables}

Table 1: Specificity of detection using primers for gyrB, gapA, rtxA and a 954-bp fragment of plasmid pB1067 tested on clinical and environmental isolates of $V$. nigripulchritudo and $V$. penaeicida as well as others Vibrio spp. and non-Vibrio isolates using optimized multiplex PCR. Note: [a] ATCC, American Type Culture Collection; CIP, Collection de l'Institut Pasteur; LMG, Laboratorium voor Microbiologie, Gent [b] virulence for L. stylirostris: NP, non-pathogenic (0-20\% mortality); MP, moderately pathogenic (20-80\%); HP, highly pathogenic (80-100\%) [c] (+) indicates a positive amplification, (-) a negative amplification, IAC: Internal Amplification Control.

\begin{tabular}{|c|c|c|c|c|c|c|c|}
\hline \multirow{2}{*}{ species } & \multirow{2}{*}{ source } & \multirow{2}{*}{ isolate name $^{a}$ and pathotype ${ }^{b}$} & \multicolumn{5}{|c|}{ Multiplex PCR results ${ }^{c}$} \\
\hline & & & IAC & $p B 1067$ & $r t x A$ & gyr $B$ & gapA \\
\hline \multirow{4}{*}{ Vibrio nigripulchritudo } & Reference strain & CIP $103336^{\mathrm{T}}$ & & - &.-- & + & \\
\hline & \multirow{3}{*}{$\begin{array}{l}\text { field isolates sampled in New } \\
\text { Caledonian shrimp farms }\end{array}$} & $\begin{array}{l}\text { highly pathogenic (HP) : SFn1, SFn2, SFn27, SFn49, } \\
\text { SFn105, SFn106, SFn127, SFn128, SFn135, POn2, POn19, } \\
\text { AgMn7, AgMn8, AgMn9, AgMn10, AgMn12, AgMn13 }\end{array}$ & - & + & + & + & - \\
\hline & & $\begin{array}{l}\text { moderately pathogenic (MP) : AQn1, AQn2, BDn1, BDn2, } \\
\text { BLFn1, BLFn2, ENn2, Fn1, MT1, Wn1, Wn13 }\end{array}$ & - & - & + & + & - \\
\hline & & $\begin{array}{l}\text { non pathogenic (NP) : AgMn1, AgMn3, ENn1, ESn2, Fn2, } \\
\text { FTn1, POn4, POn10, POn12, POn13, SFn115, SFn118, } \\
\text { SOn1, SOn2, SFn115, SFn118 }\end{array}$ & + & - & - & + & - \\
\hline \multirow{2}{*}{ Vibrio penaeicida } & Reference strain & $\mathrm{KH}-1^{\mathrm{T}}$ & + & - & - & - & + \\
\hline & $\begin{array}{l}\text { field isolates sampled in New } \\
\text { Caledonian shrimp farms }\end{array}$ & $\begin{array}{l}\text { AM101, AM107, AM108, AQ103, AQ105, AQ112, AQ120, } \\
\text { BD1, BD2, BD3, BLF2, F5, PO1, PO2, SB2, SF140, SV4 }\end{array}$ & + & - & - & - & + \\
\hline Vibrio splendidus & Reference strain & LMG4042T & + & - & - & - & - \\
\hline Vibrio tasmaniensis & Reference strain & LMG20012T & + & - & - & - & - \\
\hline Vibrio pelagius & Reference strain & LMG3897T & + & - & - & - & - \\
\hline Vibrio chagasii & Reference strain & LMG16745 & + & - & - & - & - \\
\hline Vibrio pacinii & Reference strain & LMG19999 & + & - & - & - & - \\
\hline Vibrio harveyi & Reference strain & LMG7890 & + & - & - & - & - \\
\hline Vibrio carchariae & Reference strain & $02 / 001$ & + & - & - & - & - \\
\hline Vibrio nereis & Reference strain & LMG3895T & + & - & - & - & - \\
\hline Vibrio cyclitrophicus & Reference strain & LMG21359T & + & - & - & - & - \\
\hline Vibrio orientalis & Reference strain & LMG7897 & + & - & - & - & - \\
\hline Escherichia coli & Reference strain & ATCC 25922 & + & - & - & - & - \\
\hline Pseudomonas aeruginosa & Reference strain & ATCC 27853 & + & - & - & - & - \\
\hline Staphylococcus aureus & Reference strain & ATCC 25923 & + & - & - & - & - \\
\hline Enterococcus faecalis & Reference strain & ATCC 29212 & + & - & - & - & - \\
\hline
\end{tabular}


Table 2: IAC and primers used for multiplexed PCR detection and typing of $V$. nigripulchritudo and $V$. penaeicida. Sequences of the IAC primer set (IACf and IACr) which are identical to the rtxA gene primer set (rtXA F and rtXA R) are identified in bold, while the sequence designed to amplify a 376-bp region of pUC19 is italicized.

\begin{tabular}{|c|c|c|c|c|c|}
\hline Primer & Sequence (5’-3’) & \multicolumn{2}{|c|}{ Target species and gene } & $\begin{array}{l}\text { product size } \\
\text { (bp) }\end{array}$ & References \\
\hline $\begin{array}{l}\text { gapA F } \\
\text { gapA R }\end{array}$ & $\begin{array}{l}\text { ACTGCACGTAAGCACATCACTGCG } \\
\text { TAGAACGCCCTTTAGAGGACCT }\end{array}$ & $V \cdot$ penaeicida & $\begin{array}{l}\text { glyceraldehyde-3-phosphate } \\
\text { dehydrogenase gene (gapA) }\end{array}$ & 504 & This study \\
\hline $\begin{array}{l}\text { gyrB F } \\
\text { gyrB R }\end{array}$ & $\begin{array}{l}\text { AAAACCCGAACGAAGCGAAAAC } \\
\text { ACCTTTCAGTGGCAAGATGGCT }\end{array}$ & V. nigripulchritudo & DNA gyrase gene (gyrB) & 257 & $\begin{array}{l}\text { This study and } \\
\text { [9] }\end{array}$ \\
\hline $\begin{array}{l}\operatorname{rtxA} F \\
\operatorname{rtxA} R\end{array}$ & $\begin{array}{l}\text { TTGGCGGGTAAGCACCCCGA } \\
\text { GTCGGAGACACCGGTGCGTT }\end{array}$ & $\begin{array}{l}V . \text { nigripulchritudo } \\
\text { pathotype MP and HP }\end{array}$ & RTX A gene (RtxA) & 642 & This study \\
\hline $\begin{array}{l}\text { pSFn1-6020 } \\
\text { pSFn1-6974 }\end{array}$ & $\begin{array}{l}\text { TGTCTTCTGGATCGCTTCGCC } \\
\text { CGTCGTAAGGAGCGATAAGCC }\end{array}$ & $\begin{array}{l}\text { V. nigripulchritudo } \\
\text { pathotype HP }\end{array}$ & $\begin{array}{l}954 \text { bp fragment from } \\
\text { plasmid pB1067 }\end{array}$ & 954 & [27] \\
\hline $\begin{array}{l}\text { IACf } \\
\text { IACr }\end{array}$ & $\begin{array}{l}\text { TTGGCGGGTAAGCACCCCGA GCTCTTCCGCTTCCTCGCTCA } \\
\text { GTCGGAGACACCGGTGCGTTATCCGGTAAGCGGCAGGGTC }\end{array}$ & \multicolumn{2}{|c|}{ Internal amplification control (IAC) } & 376 & This study \\
\hline
\end{tabular}


Table 3: Detection of $V$. penaeicida and $V$. nigripulchritudo by culture-based methods and multiplex PCR in moribund shrimp sampled during mortality outbreaks occurring in 10 different shrimp farms of New Caledonia between January 2008 and December 2010. Note: ND, not determined; MP, moderately pathogenic; HP, highly pathogenic

\begin{tabular}{|c|c|c|c|c|}
\hline Farm name & sampling date & Isolate name & $\begin{array}{c}\text { Presumptive phenotypic } \\
\text { identification }\end{array}$ & $\begin{array}{c}\text { Multiplex PCR } \\
\text { identification }\end{array}$ \\
\hline \multirow{4}{*}{ Farm A } & 08/04/2008 & IFNC08020 & V. nigripulchritudo & V. nigripulchritudo MP \\
\hline & $08 / 04 / 2008$ & IFNC08021 & V. nigripulchritudo & V. nigripulchritudo $\mathbf{M P}$ \\
\hline & 22/10/2009 & $\begin{array}{l}\text { IFNC09030 } \\
\text { IFNC09031 } \\
\text { IFNC09032 } \\
\text { IFNC09035 } \\
\text { IFNC09036 } \\
\end{array}$ & $\begin{array}{l}\text { ND } \\
\text { ND } \\
\text { ND } \\
\text { ND } \\
\text { ND }\end{array}$ & $\begin{array}{c}\text { negative } \\
\text { negative } \\
\text { negative } \\
\text { negative } \\
\text { negative }\end{array}$ \\
\hline & 26/10/2009 & $\begin{array}{l}\text { IFNC09038 } \\
\text { IFNC09039 }\end{array}$ & $\begin{array}{l}\text { ND } \\
\text { ND }\end{array}$ & $\begin{array}{l}\text { negative } \\
\text { negative }\end{array}$ \\
\hline Farm B & $08 / 12 / 2010$ & IFNC10045 & $V$. penaeicida & $V$. penaeicida \\
\hline \multirow{5}{*}{ Farm C } & 23/01/2008 & $\begin{array}{l}\text { IFNC08001 } \\
\text { IFNC08002 } \\
\text { IFNC08003 } \\
\text { IFNC08004 }\end{array}$ & $\begin{array}{l}\text { V. nigripulchritudo } \\
\text { V. nigripulchritudo } \\
\text { ND } \\
\text { V. nigripulchritudo }\end{array}$ & $\begin{array}{l}\text { V. nigripulchritudo } \\
\text { V. nigripulchritudo } \\
\text { V. nigripulchritudo } \\
\text { V. nigripulchritudo }\end{array}$ \\
\hline & $21 / 01 / 2009$ & $\begin{array}{l}\text { IFNC09005 } \\
\text { IFNC09006 } \\
\end{array}$ & $\begin{array}{l}\text { V. nigripulchritudo } \\
\text { V. nigripulchritudo }\end{array}$ & $\begin{array}{l}\text { V. nigripulchritudo } \\
\text { V. nigripulchritudo }\end{array}$ \\
\hline & 23/03/2010 & $\begin{array}{l}\text { IFNC10027 } \\
\text { IFNC10025 } \\
\end{array}$ & $\begin{array}{l}\text { V. nigripulchritudo } \\
\text { V. penaeicida } \\
\end{array}$ & $\begin{array}{l}\text { V. nigripulchritudo } \\
\text { V. penaeicida } \\
\end{array}$ \\
\hline & $24 / 03 / 2010$ & $\begin{array}{l}\text { IFNC10026 } \\
\text { IFNC10024 } \\
\text { IFNC10028 } \\
\end{array}$ & $\begin{array}{l}\text { V. nigripulchritudo } \\
\text { V. penaeicida } \\
\text { V. penaeicida } \\
\end{array}$ & $\begin{array}{l}\text { V. nigripulchritudo } \\
\text { V. penaeicida } \\
\text { V. penaeicida } \\
\end{array}$ \\
\hline & $27 / 04 / 2010$ & $\begin{array}{l}\text { IFNC10032 } \\
\text { IFNC10033 } \\
\end{array}$ & $\begin{array}{l}\text { V. penaeicida } \\
V . \text { penaeicida } \\
\end{array}$ & $\begin{array}{l}\text { V. penaeicida } \\
V . \text { penaeicida } \\
\end{array}$ \\
\hline Farm D & $10 / 03 / 2010$ & IFNC10029 & V. nigripulchritudo & V. nigripulchritudo MP \\
\hline \multirow{9}{*}{ Farm E } & 28/10/2008 & $\begin{array}{l}\text { IFNC08037 } \\
\text { IFNC08038 }\end{array}$ & $\begin{array}{l}V . \text { penaeicida } \\
V . \text { penaeicida }\end{array}$ & $\begin{array}{l}V . \text { penaeicida } \\
V . \text { penaeicida }\end{array}$ \\
\hline & 04/06/2009 & $\begin{array}{l}\text { IFNC09018 } \\
\text { IFNC09019 } \\
\end{array}$ & $\begin{array}{l}V . \text { penaeicida } \\
V . \text { penaeicida }\end{array}$ & $\begin{array}{l}V . \text { penaeicida } \\
V . \text { penaeicida }\end{array}$ \\
\hline & $11 / 06 / 2009$ & $\begin{array}{l}\text { IFNC09020 } \\
\text { IFNC09021 } \\
\end{array}$ & $\begin{array}{l}V . \text { penaeicida } \\
V . \text { penaeicida }\end{array}$ & $\begin{array}{l}V . \text { penaeicida } \\
V . \text { penaeicida }\end{array}$ \\
\hline & 01/10/2009 & $\begin{array}{l}\text { IFNC09024 } \\
\text { IFNC09025 } \\
\end{array}$ & $\begin{array}{l}V . \text { penaeicida } \\
V . \text { penaeicida }\end{array}$ & $\begin{array}{c}\text { negative } \\
V . \text { penaeicida } \\
\end{array}$ \\
\hline & $16 / 10 / 2009$ & $\begin{array}{l}\text { IFNC09042 } \\
\text { IFNC09043 } \\
\end{array}$ & $\begin{array}{l}V . \text { penaeicida } \\
V . \text { penaeicida }\end{array}$ & $\begin{array}{l}. \text { penaeicida } \\
V . \text { penaeicida }\end{array}$ \\
\hline & 20/03/2010 & $\begin{array}{l}\text { IFNC10018 } \\
\text { IFNC10019 } \\
\text { IFNC10020 } \\
\end{array}$ & $\begin{array}{l}V \text {. penaeicida } \\
V . \text { penaeicida } \\
V . \text { penaeicida } \\
\end{array}$ & $\begin{array}{l}\text { V. penaeicida } \\
V . \text { penaeicida } \\
V . \text { penaeicida } \\
\end{array}$ \\
\hline & $21 / 03 / 2010$ & $\begin{array}{l}\text { IFNC10021 } \\
\text { IFNC10022 } \\
\text { IFNC10023 } \\
\end{array}$ & $\begin{array}{c}\text { penaeicida } \\
\text { V. nigripulchritudo } \\
\text { V. nigripulchritudo } \\
\end{array}$ & $\begin{array}{c}\text { penaeicida } \\
\text { V. nigripulchritudo } \mathbf{M P} \\
\text { V. nigripulchritudo } \mathbf{M P} \\
\end{array}$ \\
\hline & 08/05/2010 & $\begin{array}{l}\text { IFNC10037 } \\
\text { IFNC10038 } \\
\text { IFNC10039 } \\
\end{array}$ & $\begin{array}{l}V \text {. penaeicida } \\
V . \text { penaeicida } \\
V . \text { penaeicida } \\
\end{array}$ & $\begin{array}{l}V . \text { penaeicida } \\
V . \text { penaeicida } \\
V . \text { penaeicida }\end{array}$ \\
\hline & $06 / 12 / 2010$ & IFNC10044 & V. penaeicida & negative \\
\hline \multirow{3}{*}{ Farm F } & \multirow{3}{*}{ 22/10/2009 } & IFNC09033 & ND & negative \\
\hline & & IFNC09034 & ND & negative \\
\hline & & IFNC09037 & $\mathrm{ND}$ & negative \\
\hline Farm G & $14 / 01 / 2009$ & IFNC09001 & V. nigripulchritudo & V. nigripulchritudo HP \\
\hline
\end{tabular}




\begin{tabular}{|c|c|c|c|c|}
\hline & & $\begin{array}{l}\text { IFNC09002 } \\
\text { IFNC09003 } \\
\text { IFNC09004 }\end{array}$ & $\begin{array}{l}\text { V. nigripulchritudo } \\
\text { V. nigripulchritudo } \\
\text { V. nigripulchritudo }\end{array}$ & $\begin{array}{l}\text { V. nigripulchritudo HP } \\
\text { V. nigripulchritudo HP } \\
\text { V. nigripulchritudo HP }\end{array}$ \\
\hline \multirow{4}{*}{ Farm $\mathbf{H}$} & \multirow{2}{*}{$26 / 04 / 2010$} & IFNC10030 & V. nigripulchritudo & V. nigripulchritudo HP \\
\hline & & IFNC10031 & V. nigripulchritudo & V. nigripulchritudo HP \\
\hline & \multirow{2}{*}{$24 / 03 / 2009$} & IFNC09014 & V. nigripulchritudo & V. nigripulchritudo HP \\
\hline & & IFNC09015 & V. nigripulchritudo & V. nigripulchritudo HP \\
\hline \multirow{10}{*}{ Farm I } & $25 / 02 / 2008$ & $\begin{array}{l}\text { IFNC08005 } \\
\text { IFNC08006 } \\
\text { IFNC08007 } \\
\text { IFNC08008 } \\
\text { IFNC08009 } \\
\text { IFNC08010 }\end{array}$ & $\begin{array}{l}\text { V. nigripulchritudo } \\
V . \text { nigripulchritudo } \\
V . \text { nigripulchritudo } \\
\text { V. nigripulchritudo } \\
\text { ND } \\
\text { ND } \\
\end{array}$ & $\begin{array}{l}\text { V. nigripulchritudo } \\
\text { V. nigripulchritudo } \\
\text { V. nigripulchritudo } \\
\text { V. nigripulchritudo } \\
\text { V. nigripulchritudo } \\
\text { V. nigripulchritudo }\end{array}$ \\
\hline & $20 / 03 / 2008$ & $\begin{array}{l}\text { IFNC08014 } \\
\text { IFNC08015 } \\
\text { IFNC08016 } \\
\text { IFNC08017 } \\
\text { IFNC08018 } \\
\text { IFNC08019 }\end{array}$ & $\begin{array}{l}\text { V. nigripulchritudo } \\
\text { V. nigripulchritudo } \\
\text { V. nigripulchritudo } \\
\text { V. nigripulchritudo } \\
\text { V. nigripulchritudo } \\
\text { V. nigripulchritudo }\end{array}$ & $\begin{array}{l}\text { V. nigripulchritudo } \\
\text { V. nigripulchritudo } \\
\text { V. nigripulchritudo } \\
\text { V. nigripulchritudo } \\
\text { V. nigripulchritudo } \\
\text { V. nigripulchritudo }\end{array}$ \\
\hline & $08 / 04 / 2008$ & $\begin{array}{l}\text { IFNC08024 } \\
\text { IFNC08025 }\end{array}$ & $\begin{array}{l}\text { V. nigripulchritudo } \\
\text { V. nigripulchritudo }\end{array}$ & $\begin{array}{l}\text { V. nigripulchritudo } \mathbf{M P} \\
\text { V. nigripulchritudo } \mathbf{M P}\end{array}$ \\
\hline & $26 / 05 / 2008$ & $\begin{array}{l}\text { IFNC08026 } \\
\text { IFNC08027 } \\
\text { IFNC08028 }\end{array}$ & $\begin{array}{l}\text { V. nigripulchritudo } \\
\text { V. nigripulchritudo } \\
\text { V. penaeicida }\end{array}$ & $\begin{array}{l}\text { V. nigripulchritudo } \mathbf{H P} \\
\text { V. nigripulchritudo } \mathbf{M P} \\
\text { V. penaeicida }\end{array}$ \\
\hline & $17 / 10 / 2008$ & $\begin{array}{l}\text { IFNC08035 } \\
\text { IFNC08036 }\end{array}$ & $\begin{array}{l}\text { V. penaeicida } \\
V . \text { penaeicida }\end{array}$ & $\begin{array}{l}V . \text { penaeicida } \\
V . \text { penaeicida }\end{array}$ \\
\hline & $30 / 12 / 2008$ & $\begin{array}{l}\text { IFNC08044 } \\
\text { IFNC08045 }\end{array}$ & $\begin{array}{l}\text { V. nigripulchritudo } \\
\text { V. nigripulchritudo }\end{array}$ & $\begin{array}{l}\text { V. nigripulchritudo } \mathbf{M P} \\
\text { V. nigripulchritudo } \mathbf{M P}\end{array}$ \\
\hline & 28/01/2009 & $\begin{array}{l}\text { IFNC09007 } \\
\text { IFNC09008 }\end{array}$ & $\begin{array}{l}\text { V. nigripulchritudo } \\
\text { V. nigripulchritudo }\end{array}$ & $\begin{array}{l}\text { V. nigripulchritudo MP } \\
\text { V. nigripulchritudo } \mathbf{M P}\end{array}$ \\
\hline & 23/12/2009 & $\begin{array}{l}\text { IFNC10001 } \\
\text { IFNC10002 } \\
\text { IFNC10003 } \\
\text { IFNC10004 }\end{array}$ & $\begin{array}{l}V . \text { penaeicida } \\
V . \text { penaeicida } \\
V . \text { penaeicida } \\
V . \text { penaeicida }\end{array}$ & $\begin{array}{l}\text { V. penaeicida } \\
V . \text { penaeicida } \\
V . \text { penaeicida } \\
V . \text { penaeicida }\end{array}$ \\
\hline & 03/03/2010 & $\begin{array}{l}\text { IFNC10008 } \\
\text { IFNC10009 } \\
\text { IFNC10010 } \\
\text { IFNC10011 }\end{array}$ & $\begin{array}{l}V . \text { nigripulchritudo } \\
\text { V. nigripulchritudo } \\
\text { V. nigripulchritudo } \\
\text { V. nigripulchritudo }\end{array}$ & $\begin{array}{l}\text { V. nigripulchritudo } \mathbf{H P} \\
\text { V. nigripulchritudo } \mathbf{H P} \\
\text { V. nigripulchritudo } \mathbf{H P} \\
\text { V. nigripulchritudo } \mathbf{H P}\end{array}$ \\
\hline & 09/03/2010 & $\begin{array}{l}\text { IFNC10012 } \\
\text { IFNC10013 } \\
\text { IFNC10014 } \\
\text { IFNC10015 } \\
\text { IFNC10016 } \\
\text { IFNC10017 } \\
\end{array}$ & $\begin{array}{l}\text { V. nigripulchritudo } \\
\text { V. nigripulchritudo } \\
\text { V. nigripulchritudo } \\
\text { V. penaeicida } \\
\text { V. penaeicida } \\
\text { V. penaeicida } \\
\end{array}$ & $\begin{array}{l}\text { V. nigripulchritudo HP } \\
\text { V. nigripulchritudo HP } \\
\text { V. nigripulchritudo HP } \\
\text { V. penaeicida } \\
\text { V. penaeicida } \\
\text { V. penaeicida } \\
\end{array}$ \\
\hline Farm $\mathbf{J}$ & 09/04/2008 & $\begin{array}{l}\text { IFNC08022 } \\
\text { IFNC08023 }\end{array}$ & $\begin{array}{c}\text { ND } \\
\text { V. nigripulchritudo }\end{array}$ & $\begin{array}{c}\text { V. nigripulchritudo } \\
\text { V. nigripulchritudo MP }\end{array}$ \\
\hline
\end{tabular}




\section{Figures}

Figure 1: detection limits of the multiplex PCR. DNA extracted from pure cultures of $V$. nigripulchritudo SFn1 and $V$. penaeicida AM101 was coamplified with IAC using multiplex PCR. Genomic DNA was serially diluted tenfold from $10 \mathrm{ng}$ to $0.1 \mathrm{pg}$ and amplified by PCR with a defined IAC concentration (284 copies in every reaction). The amplicons corresponding to gyrB, gapA, rtxA and to a fragment of plasmid pB1067, with predicted sizes of 257, 504, 642 and 954 bp respectively, are indicated by yellow arrows. Lane M, 100 bp plus DNA ladder (GelPilot, QIAGEN); lanes 1-6, varying concentrations of a combination of V. nigripulchritudo SFn1 and V. penaeicida AM101 DNA (lane 1, $10 \mathrm{ng}$; lane 2, $1 \mathrm{ng}$; lane 3, $0.1 \mathrm{ng}$; lane 4, $10 \mathrm{pg}$, lane 5, $1 \mathrm{pg}$; lane 6, $0.1 \mathrm{pg}$ ); lane 7, no DNA template (negative control); lane 8, IAC DNA template (positive control).

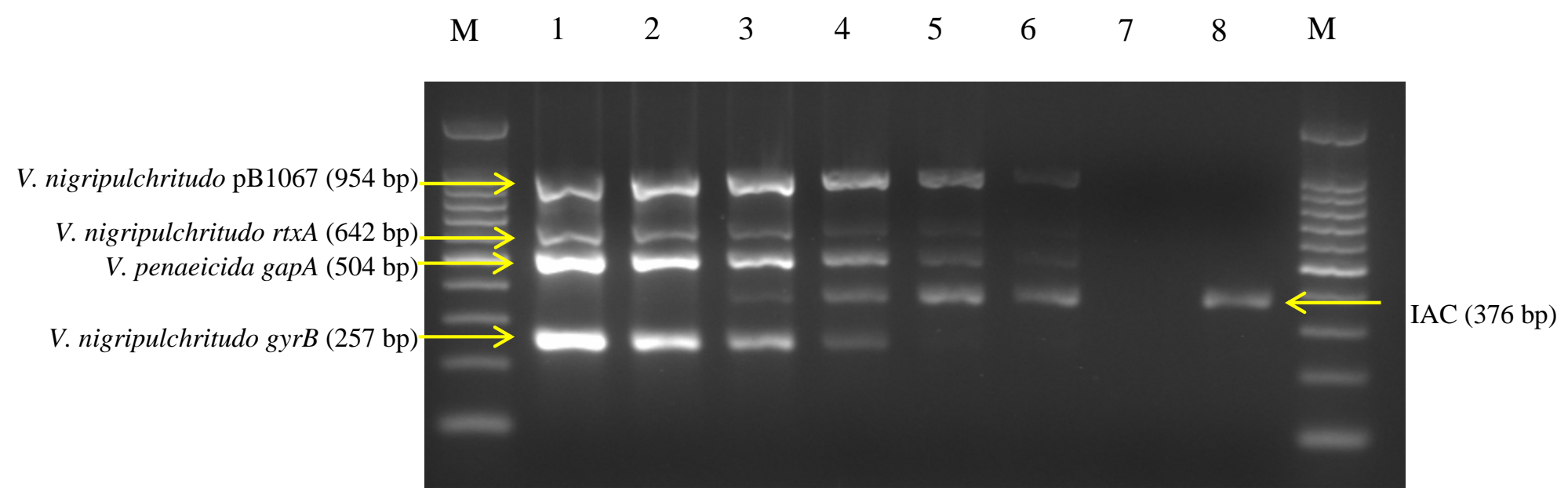


Figure 2: DNA extracted from $V$. penaeicida AM101 (A) or V. nigripulchritudo SFn1 (B) bacterial cells suspended in hemolymph of naïve shrimp and coamplified with IAC using multiplex PCR. Bacterial cells were serially diluted tenfold in hemolymph and the extracted DNA was amplified by PCR with a defined IAC concentration (284 copies). Lane M, 100 bp plus DNA ladder (GelPilot, QIAGEN); lanes 1-7, PCR products amplified from DNA extracted from 10 -fold dilutions (from $2.10^{6}$ to $2 \mathrm{cfu} / \mathrm{ml}$ ); lane 8 , no DNA template (negative control); lane 9, IAC DNA template (positive control).
$\mathrm{M}$
$\begin{array}{llllllll}M & 1 & 2 & 3 & 4 & 5 & 6 & 7\end{array}$
$8 \quad 9 \quad \mathrm{M}$

(A)

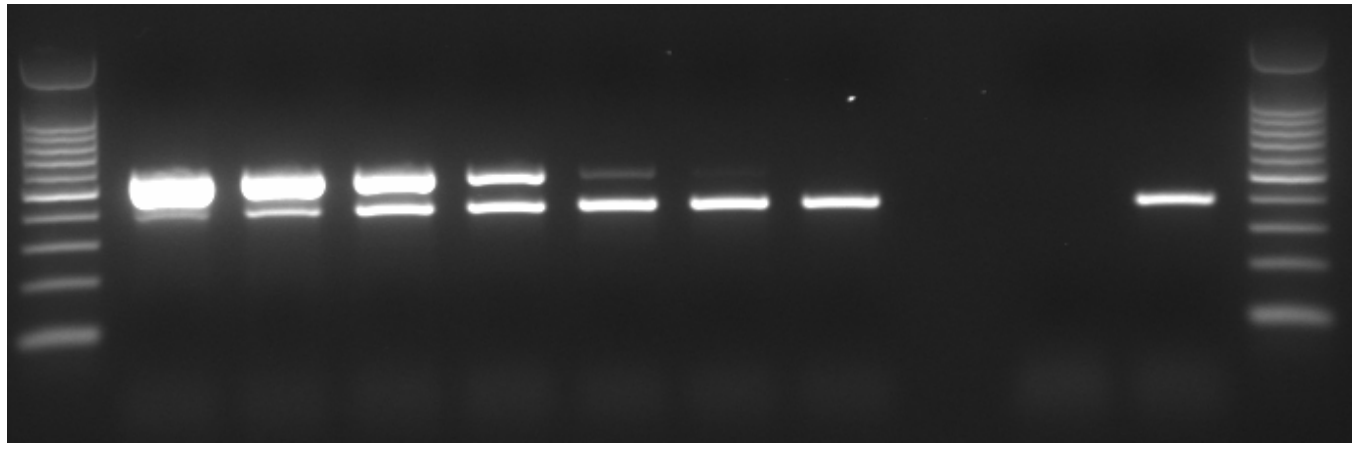

(B)

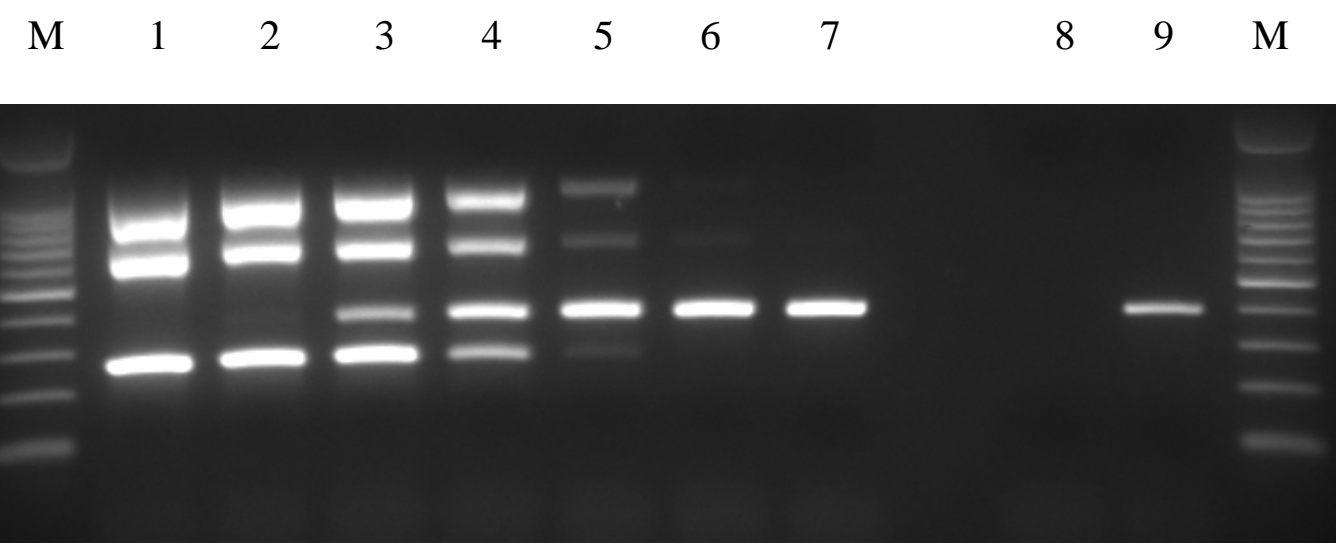


Figure 3: Map of New-Caledonia indicating the geographical localization of the 10 shrimp farms (designated $A$ to $\mathrm{J}$ ) sampled in this study.

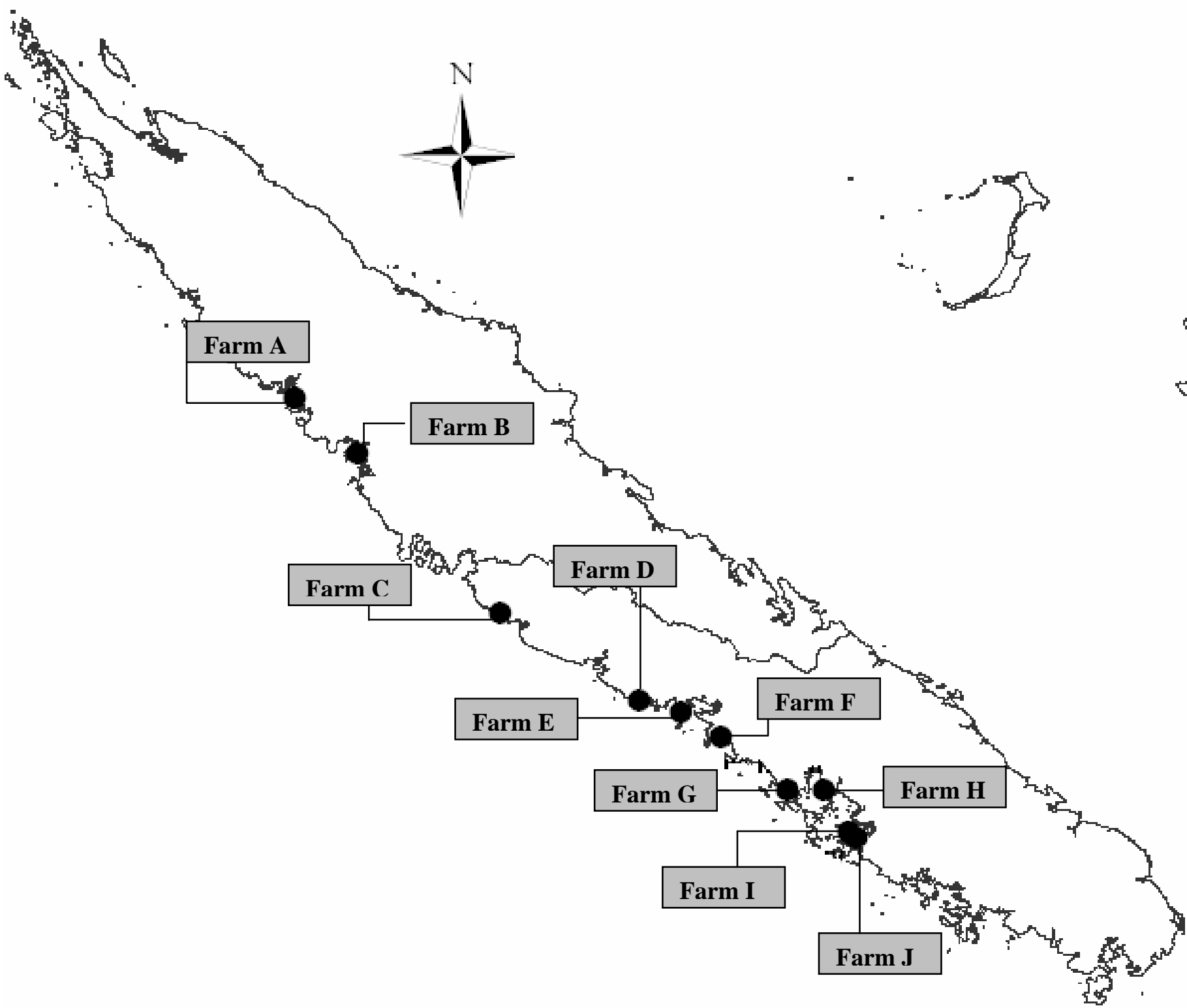

$\mathrm{km}$

$\begin{array}{llllll}0 & 10 & 20 & 40 & 60 & 80\end{array}$ 
Figure 4: Shrimp mortality in response to injection of bacterial culture supernatants. Animals $(n=8)$ were injected with $100 \mu \mathrm{l}$ of bacterial supernatant prepared from overnight cultures grown in MB 5X as described previously [18]. Survival was assessed after $24 \mathrm{~h}$.

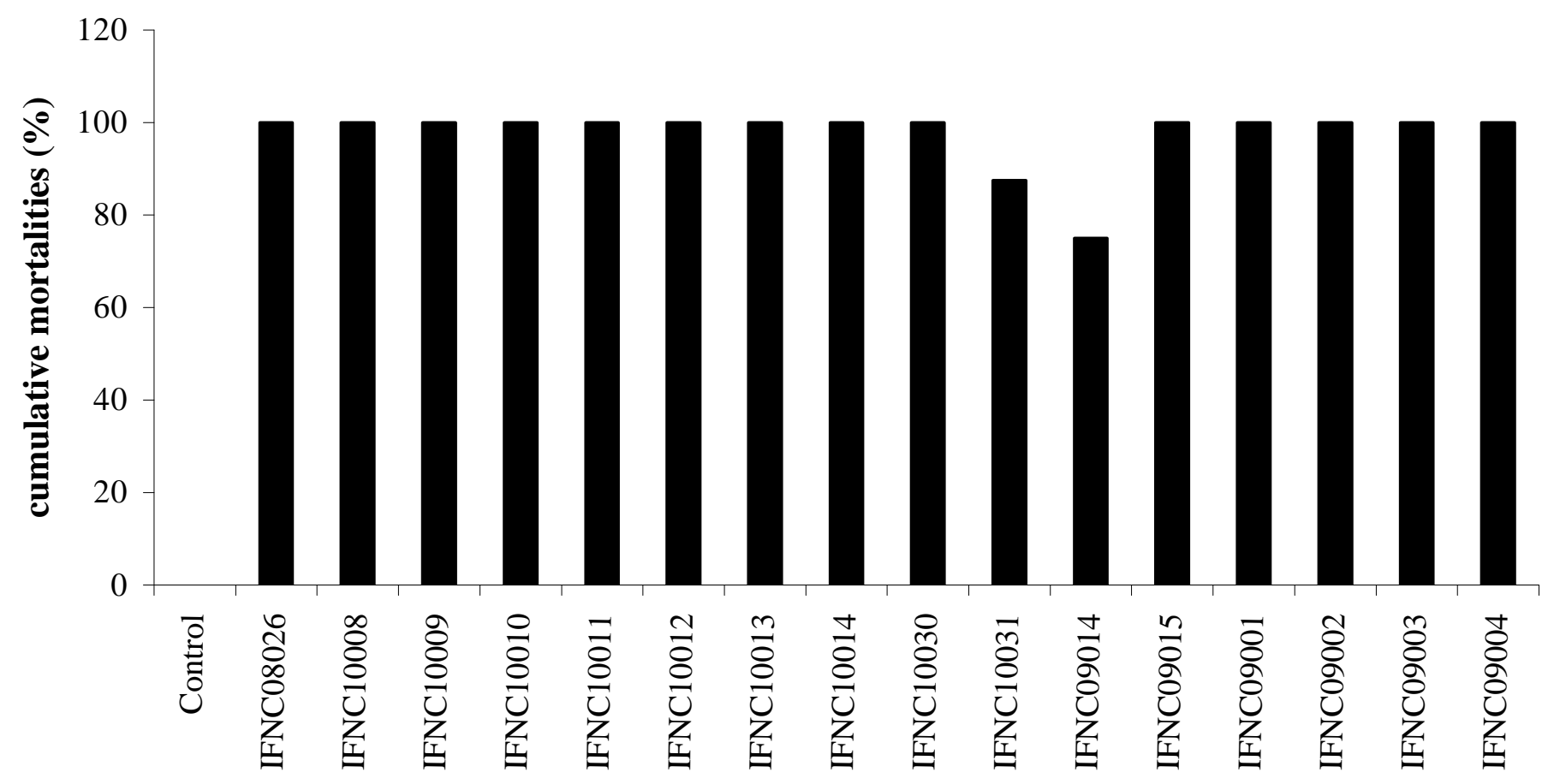




\section{Supplementary data}

Figure S1: multiplex PCR-based detection of $V$. nigripulchritudo strain SFn1 and $V$. penaeicida strain AM101 from the hemolymph of experimentally infected shrimp. Lane $M$, $100 \mathrm{bp}$ plus DNA ladder (GelPilot, QIAGEN); lanes 1-6, PCR products of purified DNA extracted from control (unchallenged) shrimp; lanes 7-12, PCR products of purified DNA extracted from shrimp infected by $V$. nigripulchritudo SFn1; lanes 13-18, PCR products of purified DNA extracted from shrimp infected by $V$. penaeicida AM101; (-) no template control; (+) IAC in the absence of bacterial genomic DNA.

A

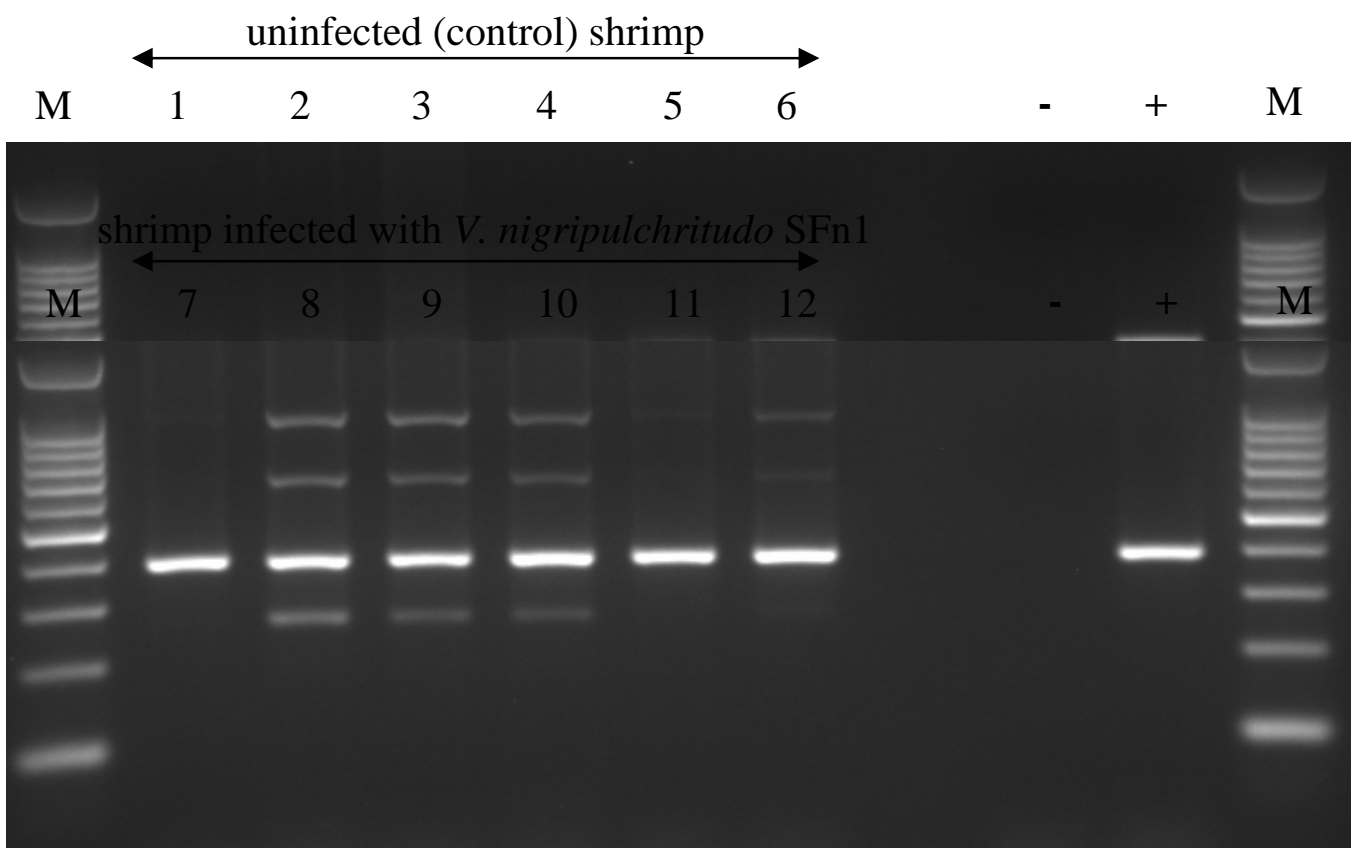

shrimp infected with $V$. penaeicida AM101

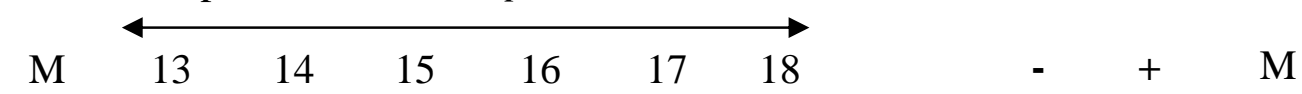

C

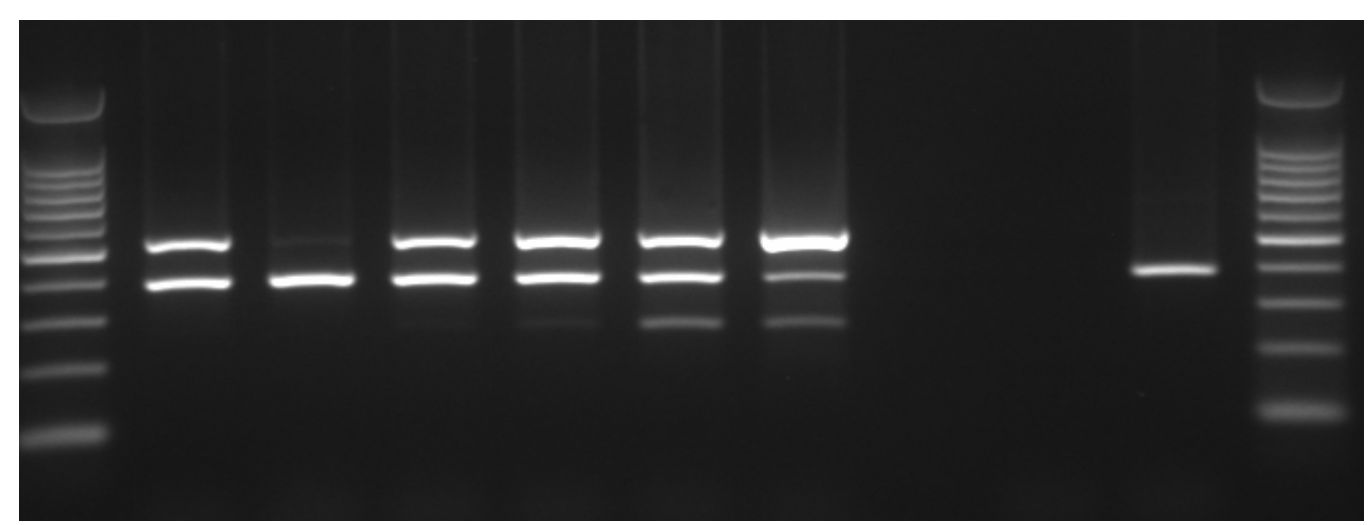

